\title{
Book Review: Susana Bayó Belenguer, Eiléan Ní Chuilleanáin, \& Cormac Ó Cuilleanáin, editors, assisted by Giulia Zuodar (2013). TRANSLATION RIGHT OR WRONG. Four Courts Press, Dublin.Hardback 304pp. June 2013; ISBN:978-1-84682-372-5
}

\author{
Eithne O’Connell \\ Centre for Translation and Textual Studies. \\ School of Applied Language and Intercultural Studies. \\ Dublin City University, Glasnevin, Dublin 9, Ireland
}

Received: $12-07$ - 2013

doi:10.7575/aiac.ijclts.v.1n.3p.48
Accepted: $14-10-2013$

Published: $15-10-2013$

URL: http://dx.doi.org/10.7575/aiac.ijclts.v.1n.3p.48

\section{Review}

\section{TRANSLATION RIGHT OR WRONG}

This collection of essays published in 2013 has its origins in an international conference held in Trinity College Dublin in 2009. The three editors (assisted by Ph.D. student Giulia Zuodar), are Susana Bayó Belenguer, Eiléan Ní Chuilleanáin and Cormac Ó Cuilleanáin, members of faculty at Trinity College where they teach Spanish, English and Italian respectively, as well as lecturing on the MA in literary translation there. The title of the collection could possibly cause some unease, seeming to hark back, as it does, to the traditional tendency of commentators over millennia to view translation as a question of success or failure rather than of endless possibilities. To once again try to approach translation from a right versus wrong perspective could possibly seem a retrograde step but any fear in that regard in relation to this volume is unfounded. The anachronistic ring to the title is deliberate and provocative but in reality there is nothing at all predictable, rehashed or a wearisome about this truly exciting collection of essays. Somewhat unusually, the work starts with a substantial introduction of almost 30 pages, in which the editors resist the temptation to limit themselves simply to short summaries of the chapters that follow and opt instead to launch into an invigorating and far-ranging discussion of the rights and wrongs of translation across civilisations and centuries in a wholly success effort to bring "new perspectives to bear on a long-lived and sometimes controversial issue". Here you can find references to Sappho, St Jerome and Luther, on one page and, Milan Kundera, and translation theorist, James Holmes, on the next. One chapter explains the subtleties of fan-translation in contemporary pop culture while another deals with the Quechua language of the Andes. Refreshingly, the work includes output from a more diverse range of scholars and topics than would typically be represented at a single conference or in a single publication. Over the last 20 or so years, the growth of interest in translation studies has been such that there is frequently a tendency for scholarship on, say, literary translation to be accommodated in one type of conference, journal or book where research on audiovisual translation, for example, would be unlikely to appear side-by-side. Here, however, subtitles are discussed in one breath and literary classics in the next.

The book, which runs to some 304 pages, is a handsome hardback production from Dublin academic publishers, Four Courts Press, and includes biographical notes on contributors, a bibliography and index. The editors seem to have taken their task seriously, preparing a well written volume with only a single typo and no errors so far as the reviewer was able to discern. The academic standing of the contributors ranges from well-established professors and senior lecturers to $\mathrm{Ph} . \mathrm{D}$. students but the writing is, more or less, of a consistently high standard. It is particularly gratifying to note that those who are not native speakers of English managed, with or without the assistance of the editors, to produce work in excellent academic English. This is by no means the norm and I have commented elsewhere on the lamentable tendency in many translation studies publications, mainly edited volumes, to accept work that clearly has not been thoroughly proofread by a competent translator or editor, when any respectable publisher should insist on both. Failure on the part of editors to take this matter seriously makes a joke of much of the academic (in both senses of the word) talk of professional standards within the translation profession.

While the reach is not truly global, the Americas, Europe and Japan are represented either by topic or by author or both, but only three of the total 23 contributors, are male. This is no doubt a reflection of the fact that the preponderance of students studying languages is female. While the work is clearly aimed primarily at an academic audience, it occurs to me that it is such an interesting and varied read that it could easily also appeal to anyone with a lively mind and a casual interest in language and/or literature, popular culture, translation. Certainly, it was a truly stimulating and thoroughly enjoyable volume to review.

The book is divided into three sections: Part 1 is entitled Translation and Genre: High and Low. This is by far the longest section of the book with 10 chapters, amounting to more than half of the total. In an attempt to start at some kind of chronological beginning, the chapter by poet and translator Josephine Balmer on ancient Greek and Latin texts opens the section. Michelle Woods, formerly of Dublin City University but now at the University of New York, looks at the case of Kafka's first translator (and lover) Milena Jesenká, a woman whose letters to Kafka were destroyed, but 
whose words live on her Czech translations and in Kafka's diaries. Carmen Mangiron, (also formerly DCU but now at Universitat Autònoma de Barcelona) compares five English translations of the Japanese classic, Botchan, concluding that extratextual sociological parameters (e.g. patronage) have played a key role in the production of the translations, influencing process and product. Furthermore, she finds that the earlier translations tended to domesticate sociocultural content, whereas more recent translations preserve it, and where necessary add information to help readers. Virginia Jewiss of Yale University, herself a translator for children of Dante's Divine Comedy, compares three other translations of 'hell for kids', before presenting her own version, and explaining her translation decisions. While the versions under discussion involve distilling the truths of Dante's poem into simpler lessons, she argues that "Hell proves to be an ideal place for children to learn, and hopefully their memory of the low version will only increase the pleasure of the high one that awaits them". Literature for children is also discussed by Mette Rudvin of Università degli Studi di Bologna, who turns her attention to the Italian translations of The Jungle book and its sequel while Emer Delaney, a Ph.D. student at Trinity College Dublin shows that the translation of Crompton's classic William stories has resulted in a rather domesticated version of William arriving in Italy. Interestingly, she suggests that children domesticate cross-written texts such as the William stories, which are aimed at adults as well as children "to the bounds of their own worldviews while adults use their additional knowledge of 'foreignize' the text by admitting its additional, subtextual or intertextual possibilities".

This first section does not limit itself to works of classical literature and iconic books for children. Jane Dunnett from Swansea University turns her attention to the translation of Agatha Christie's Murder on the Orient Express into Italian. Sabine Strümper-Krobb continues the detective theme by suggesting that translators and detectives may have quite a bit in common since the linguistic sleuth first has to "identify the function and meaning of particular elements of a text in order to reconstruct them as truthfully as possible in a different language". Moreover, she claims that the "literary treatment of translation in crime and detective fiction...directs attention towards debates about authenticity and originality". Bart Defrancq of the University of Ghent looks at how insults are translated in the media, concluding that "strong insults tend not to be translated... On the other hand, less offensive insults tend to be translated but results vary from overstating to understating". A similar topic is addressed by Ilaria Parini from Università degli Studi di Milano writing about taboo and translation in audiovisual works, specifically in the dubbing into Italian of Tarantino's films. She concludes that her evidence suggests that "Italian dubbing professionals seem to believe that Italian public (sic) is probably too chaste and demure to tolerate an excessive exposure to the topic of sex, and they have identified a tolerance threshold which should not be passed". However, Parini suggests that this threshold is really much dependent on the subjectivity of individual dubbing translators.

Part 2, History and Politics of Translation, is the shortest section with just four essays. Pilar Ordóñez López, Universitat Jaume 1, Castellón discusses Ortega y Gasset's view of the translator while Sabine Dedenbach-Slazar Sáenz from Stirling University addresses the title of the book head-on. She discusses the complex meaning of a key Quechuan word muchay and shows how it was understood and translated by Christian missionaries in the colonial Andes. While missionaries hoped to suppress indigenous religious practice and convert the Andean population completely to Christianity, the Spanish colonisers' adoption of this word (meaning approximately to worship a deity) for use in Christian doctrine had the unintended consequence of contributing to a certain fusion of Christian and Inca religious concepts by the local population. Thus, paradoxically, what the Spanish thought to be the right translation turned out to be the wrong one, from their point of view, while the wrong one for the Incas turned out to be better than expected in that it enabled them to retain many elements of their own religion and combine them with Christianity.

Anne Markey, also from Trinity College Dublin, looks critically at two translations of the Irish language poetry and short stories of Irish revolutionary, educationalist and writer, Patrick Pearse. She shows evidence of censorship at work in the Fitzgerald translations both at the level of selection and interpretation whereas Campbell's work, while also problematic by virtue of expressing in English a culture that Pearse saw as essentially Gaelic, nevertheless manages to represent "the competing cultural claims that characterized their particular historical context". Simone Schroth of University College Dublin reviews German translations of works relating to Germany's Nazi past. She examines translation choices relating to Anne Frank's Het Achterhuis (The Diary of Anne Frank) and Daniel Jonah Goldhagen's Hitler's willing executioners, concluding that versions published in the immediate post-war period were deemed to require a number of editorial changes in deference to the general German reading public. She speculates that, with the passage of time, new translations of the same works may include revisions and/or translation commentaries.

Part 3 is entitled Translation Now. Kathleen Shields, who lectures in NUI Maynooth, writes about the contemporary situation in France vis á vis English translation and advertising. Examining the implications of the 1994 law on the use of the French language, she presents the translation of advertising as a good example of in vitro planning coming up against in vivo language use in an age when French feels increasingly threatened by the prevalence of English, in France and internationally. Addressing audiovisual translation, Francisca García Luque from Universidad de Málaga describes the challenges of subtitling science documentaries while Minako O'Hagan, a senior lecturer in Dublin City University, provides a fascinating upbeat appraisal of the popular craze for fan-translation. Associate professor at the Norwegian University of Science and Technology, Annjo Klungervik Greenall, presents the results of an empirical study of audience perceptions of subtitles while Alberto Fuertes Puerta of Universidad de León ends the collection with a discussion of methodology which can identify plagiarism in English-Spanish translations, a topic on which he has competed a doctoral dissertation. 
A short book review cannot do justice to the range and scholarship contained in such an eclectic volume and I have not detailed the contents of each chapter to exactly the same extent here. Rather, I have simply tried to expand a little more on those topics which particularly caught my attention, either because they were new to me or addressed a favourite topic of mine. Thus chapters mentioned in a little more depth should not be deemed to be necessarily in any way more noteworthy than others in this collection. My intention has been simply to try to whet the appetite of those who come across this review so that they will seek out this interesting and invigorating book and read it. 